Research Article

Animal Genetics

\title{
Chromosomal diversity in three species of Lycosa Latreille, 1804 (Araneae, Lycosidae): Inferences on diversification of diploid number and sexual chromosome systems in Lycosinae
}

\author{
Analiza Fernanda Cavenagh ${ }^{1}$ (D), Matheus Pires Rincão ${ }^{1}$ (D), Felipe Cordeiro Dias ${ }^{1}$ (D), \\ Antonio Domingos Brescovit ${ }^{2}$ (i) and Ana Lúcia Dias ${ }^{1}$ (B) \\ ${ }^{1}$ Universidade Estadual de Londrina, Departamento de Biologia Geral, Laboratório de Citogenética Animal \\ (LACA), Londrina, PR, Brazil. \\ ${ }^{2}$ Instituto Butantan, Laboratório de Coleções Zoológicas, São Paulo, SP, Brazil.
}

\begin{abstract}
Lycosa is one of the most speciose genera in Lycosidae, including species with different sexual chromosome systems (SCS). We carried out cytogenetic analyses in three species of $L y c o s a$, revealing that $L$. erythrognatha and $L$. sericovittata share $2 \mathrm{n} \hat{\delta}=22$ and SCS $X_{1} X_{2} 0$ while $L$. gr. nordenskjoldi presents $2 n \hat{~}=19$ and SCS XO, composed only of acrocentric chromosomes. All species shared pericentromeric heterochromatin. Nonetheless, one specimen of $L$. sericovittata carried two chromosomes with terminal heterochromatin and $L$. gr. nordenskjoldi showed four chromosomes with interstitial heterochromatin plus another chromosome with terminal C-bands. The pericentromeric heterochromatin of all species as well as the terminal heterochromatic blocks in L. sericovittata were $\mathrm{CMA}_{3}{ }^{+}$. The $18 \mathrm{~S}$ rDNA sites varied in number and type of bearing chromosomes both at inter and intrapopulational levels, with the highest variation in L. gr. nordenskjoldi. These differences may be related to gene dispersal due to the influence of transposition elements and translocation events. Despite these variations, all species shared ribosomal sites in pair 5. This study demonstrated intra and interspecific chromosomal variability of $L y c o s a$, suggesting that chromosomal rearrangements are related to the diversification of diploid number and SCS in this group of spiders.
\end{abstract}

Keywords: FISH, heterochromatin, rDNA, sex chromosomes, spiders.

Received: November 27, 2020; Accepted: November 22, 2021.

\section{Introduction}

Members of the Lycosoidea superfamily belong to the Entelegynae clade in Araneomorphae, composing a highly diverse group, with more than 6,000 species and 422 genera (World Spider Catalog, 2021) distributed in seven families: Ctenidae, Lycosidae, Oxyopidae, Pisauridae, Psechridae, Thomisidae, and Trechaleidae (Wheeler et al., 2017). Lycosidae comprises 2,400 species and 125 genera, representing nearly $50 \%$ of the species described in Lycosoidea (World Spider Catalog, 2021).

Although Lycosidae is one of the most studied families cytogenetically, chromosomal data are only available in $5 \%$ of the described species, which indicates a large gap in knowledge about carioevolutionary trends in this large and widespread group of spiders (Araujo et al, 2021). So far, the diploid number reported in species of this family ranges from 18 to 30 chromosomes, mostly acrocentric/telocentric, with a predominance of $2 n \hat{\delta}=28$ (reported in 62 of the 120 cytogenetically analyzed species). The sex chromosome system (SCS) $\mathrm{X}_{1} \mathrm{X}_{2} 0 / \mathrm{X}_{1} \mathrm{X}_{1} \mathrm{X}_{2} \mathrm{X}_{2}$ is present in $94 \%$ of the described karyotypes in Lycosidae (Araujo et al., 2021), and variations are restricted to the occurrence of $\mathrm{X} 0$ systems as observed in

Send correspondence to Ana Lúcia Dias. Universidade Estadual de Londrina, Departamento de Biologia Geral, Laboratório de Citogenética Animal (LACA), Rodovia Celso Garcia Cid, PR 445 Km 300, 86057-970, Londrina, PR, Brazil. E-mail: anadias@uel.br.
Lycosa barnesi Gravely, 1924, Wadicosa quadrifera (Gravely, 1924) (Srivastava and Shukla,1986), Lycosa gr. nordenskjoldi Tullgren, 1905, Hogna sternalis (Bertkau, 1880) (Araujo et al., 2015); $\mathrm{X}_{1} \mathrm{X}_{2} \mathrm{X}_{3} 0$ in Lycosa sp. (group thorelli) (Postiglioni and Brum-Zorrilla, 1981), and the doubtful $\mathrm{X}_{1} \mathrm{X}_{2} \mathrm{Y}$ in Lycosa sp. (Navia et al., 2006).

Furthermore, studies based on chromosome banding in Lycosidae are still scarce and usually revealed small amounts of heterochromatin at pericentromeric region as observed by Brum-Zorrilla and Cazenave (1974), Chemisquy et al. (2008) and Dolejš et al. (2011). In Lycosa, target of this study, only two (L. erythrognatha Lucas, 1836 and L. thorelli Keyserling, 1877) out of the 15 valid taxa and 19 undefined species (Lycosa sp.) with cytogenetic reports (Araujo et al., 2021) have C-band data, also showing small amounts of constitutive heterochromatin (Brum-Zorrilla and Postiglioni, 1980; Chemisquy et al., 2008).

In addition to C-banding, Chemisquy et al. (2008) analyzed the distribution of heterochromatin in Lycosidae using base-specific fluorochromes, and found heterogeneous results among the species, comprising three general patterns, as follows: a) C-band positive and GC-rich pericentromeric heterochromatin as observed in L. erythrognatha (Chemisquy et al., 2008); b) C-band positive and AT-rich pericentromeric heterochromatin as reported in Schizocosa malitiosa, L. thorelli, and Lycosa sp. by Brum-Zorrilla and Postiglioni (1980); and c) C-band negative and AT-rich terminal heterochromatin also in Lycosa sp. (Brum-Zorrilla and Postiglioni, 1980). 
On the other hand, silver nitrate staining was performed by Wise (1983) in Tigrosa georgicola (Walckenaer, 1837), cited as Lycosa georgicola, and by Dolejš et al. (2011) in Arctosa cinerea (Fabricius, 1777), A. lutetiana (Simon, 1876), Xerolycosa miniata (C.L. Koch, 1834), and X. nemeralis (Westring, 1861) to identify the nucleolar organizer regions (NORs). In those reports, two NOR-bearing chromosome pairs were invariably observed.

Subsequently, Forman et al. (2013) identified in Wadicosa fidelis (O. Pickard-Cambridge, 1872), by silver nitrate staining and fluorescent in situ hybridization (FISH) with $18 \mathrm{~S}$ rDNA probes, three and seven to ten NOR sites, respectively.

Based on these data, the goal of this study was to extend the chromosomal information in this group of spiders by including refined cytogenetic analyzes. Therefore, different chromosome banding techniques were applied to three Lycosa species from Paraná state, Brazil, to investigate karyotypic variability, presence of different SCS, heterochromatin distribution patterns and chromosome mapping of $18 \mathrm{~S}$ rDNA sites. Based on a comparative approach, we discuss some of the mechanisms that could account for the karyotype differentiation in Lycosinae species.

\section{Material and Methods}

Cytogenetic analyses were performed in three species of Lycosa, collected in five locations along the state of Paraná (Table 1). The specimens were deposited in the arachnological collection of the Laboratory of Zoological Collections at the Butantan Institute (IBSP, curator A.D. Brescovit) in São Paulo/SP, Brazil. Chromosomal preparations were obtained according to Araujo et al. (2008), using young and adult spider testicles. The slides were stained with Giemsa 3\%, and approximately 30 mitotic and meiotic cells from each individual were analyzed to determine the diploid number. The morphology and chromosome measurements were performed on 10 mitotic metaphases in the Image J program (Schneider et al., 2012) with the use of the plugin LEVAN (Sakamoto and Zacaro, 2009), according to the methodology described by Levan et al. (1964). The slides were submitted to C banding according to Sumner (1972), modified by Lui et al. (2012). The staining with base-specific fluorochromes chromomycin
$\mathrm{A}_{3}\left(\mathrm{CMA}_{3}\right)$ and 4,6'-diamidino-2'phenylindol (DAPI) was carried out according to Schweizer (1980).

Fluorescent in situ hybridization (FISH) was performed according to Schwarzacher and Heslop-Harrison (2000). The 18S rDNA probes were obtained from Ctenus ornatus (Keyserling, 1877) by Rincão et al. (2017), labeled with biotin by using the Biotin-Nick Translation Mix (Roche) kit and detected with Avidin-FITC (Invitrogen). Finally, the FISH slides were analyzed using an epifluorescence microscope (Leica DM2000), equipped with digital camera Moticam Pro 282B. The images were captured using the program Motic Images Advanced, version 3.2.

\section{Results}

Lycosa erythrognatha and $L$. sericovittata presented $2 \mathrm{n} \hat{\delta}=22$ and SCS $X_{1} X_{2} 0$ (Figure 1A, B, respectively), while L. gr. nordenskjoldi presented $2 \mathrm{n} \hat{\delta}=19$ and SCS X0 (Figure 1C); The karyotypes of the three species are entirely composed of acrocentric chromosomes. However, each species showed different sizes of the sex chromosomes: $X_{1}$ and $X_{2}$ elements are the two largest chromosomes (6.96 - $6.74 \mu \mathrm{m}$ respectively) in L. erythrognatha, where the other chromosomes vary from $5.65-3.18 \mu \mathrm{m}$; in L. sericovittata $\mathrm{X}_{1}$ is a medium-sized chromosome of $3.82 \mu \mathrm{m}$, significantly distancing itself from the first and largest pair $(6.30 \mu \mathrm{m})$ and $\mathrm{X}_{2}$ is one of the smallest elements $(2.69 \mu \mathrm{m})$, the other pairs vary $6.05-2.94 \mu \mathrm{m}$. On the other hand, the $\mathrm{X}$ chromosome is the smallest element $(3.33 \mu \mathrm{m})$ in the karyotype of L.gr. nordenskjoldi, and the other chromosomes vary from $6.48-3.88 \mu \mathrm{m}$ (Figure 1).

In meiotic cells of males from the three species, the sex chromosomes are easily visible in the pachytene nucleus due to their high condensation, being frequently observed as single mass of positive heteropycnosis (Figure 2A, E, I). The diplotene cells in L. erythrognatha and L. sericovittata (Figure 2B, F, respectively) showed 10 autosomal bivalents and two sexual univalents $\left(10 \mathrm{II}+\mathrm{X}_{1} \mathrm{X}_{2}\right)$, whereas $L$. gr. nordenskjold $i$ (Figure 2J) presented 9 autosomal bivalents and one sexual univalent $(9 \mathrm{II}+\mathrm{X})$, with predominance of terminal chiasmata in the three species. In diakinesis, sexual univalent arranged side by side or very close to each other were observed in both species with $\mathrm{X}_{1} \mathrm{X}_{2} 0 \mathrm{SCS}$ (Figure 2C, G).

Table 1 - Species analyzed and collection sites. IBSP = Collections Laboratory Zoos, Butantan Institute (curator AD Brescovit), São Paulo / SP, Brazil; $\mathrm{PR}=$ Paraná; PEMG=Mata dos Godoy State Park; PNS=Superagui National Park; UEL= State University of Londrina; PNIG=Ilha Grande National Park; PNI = Iguaçu National Park.

\begin{tabular}{|c|c|c|c|}
\hline Species & Samples $(\circlearrowleft)$ & Voucher (IBSP) & Collection location \\
\hline \multirow{4}{*}{$\begin{array}{l}\text { Lycosa erythrognatha } \\
\text { Lucas, } 1836\end{array}$} & 3 & $216040,216042,216043$ & \multirow{4}{*}{ 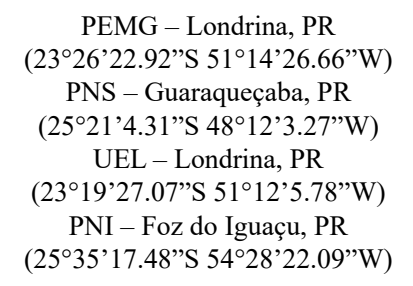 } \\
\hline & 15 & $\begin{array}{c}215907,216036,216038,216044, \\
216048,216049,216078,216088, \\
216092,216093,216094,216100, \\
216106,216108,271347\end{array}$ & \\
\hline & 4 & $166431,166432,166433,166437$ & \\
\hline & 3 & $166402,166403,166405$ & \\
\hline $\begin{array}{l}\text { Lycosa gr. } \\
\text { nordenskjoldi } \\
\text { Tullgren, } 1905\end{array}$ & $\begin{array}{l}3 \\
4\end{array}$ & $\begin{array}{c}215873,215874,271348 \\
242146,242148,271349,271350\end{array}$ & $\begin{array}{c}\text { PNS - Guaraqueçaba, PR } \\
\left(25^{\circ} 21^{\prime} 4.311^{\prime} \mathrm{S} 48^{\circ} 12^{\prime} 3.27^{\prime \prime} \mathrm{W}\right) \\
\text { PNIG - Icaraíma/Porto Camargo-PR } \\
\left(43^{\circ} 22^{\prime} 01,00{ }^{\prime} \text { 'S } 73^{\circ} 46^{\prime} 25,40^{\prime \prime} \mathrm{W}\right)\end{array}$ \\
\hline $\begin{array}{l}\text { Lycosa sericovittata } \\
\text { Mello-Leitão, } 1939\end{array}$ & 2 & 166438,167415 & $\begin{array}{c}\text { UEL - Londrina, PR } \\
\left(23^{\circ} 19^{\prime} 27.07^{\prime} \text { 'S } 51^{\circ} 12^{\prime} 5.78^{\prime \prime} \mathrm{W}\right)\end{array}$ \\
\hline
\end{tabular}




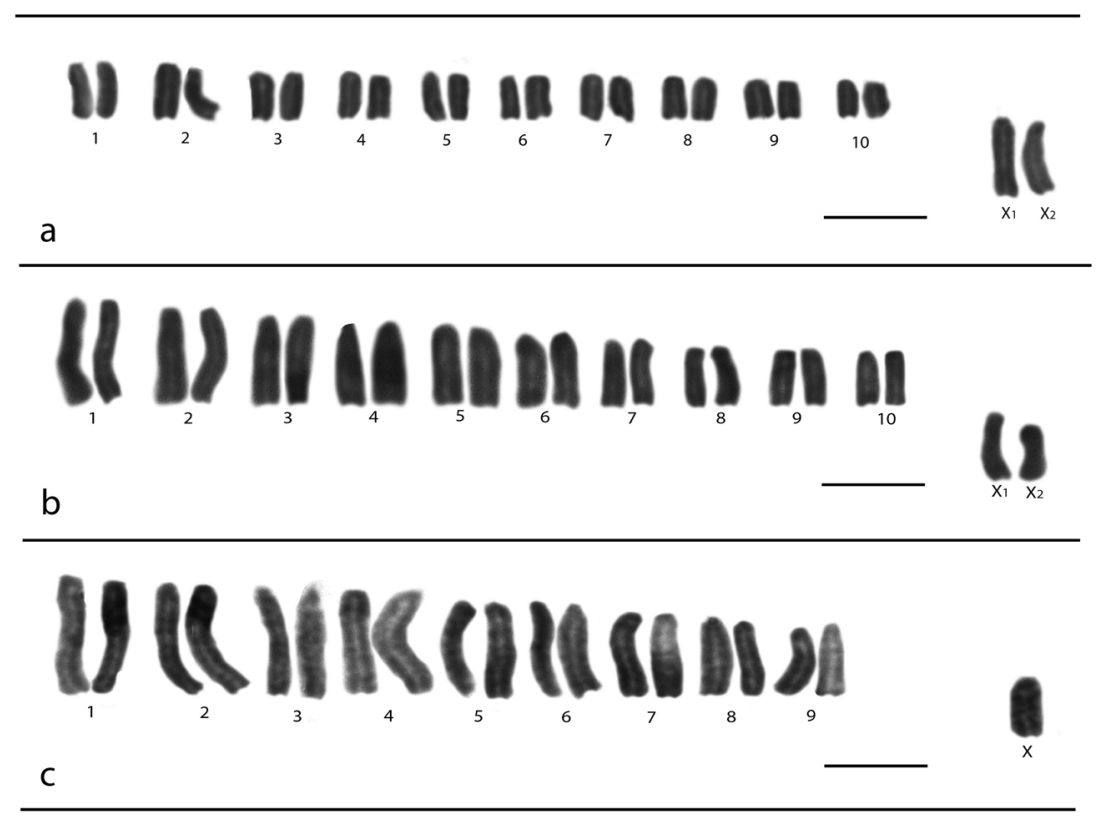

Figure 1 - Karyotypes of males of Lycosa species stained with Giemsa. A Lycosa erythrognatha, $2 \mathrm{n}^{2}=22, \mathrm{X}_{1} \mathrm{X}_{2} 0$ of the Mata dos Godoy State Park, State University of Londrina, Iguaçu National Park and Superagui National Park. B Lycosa sericovittata, $2 \mathrm{n} \partial=22, \mathrm{X}_{1} \mathrm{X}_{2} 0$ of the State University of Londrina. C Lycosa gr. nordenskjoldi, 2n $\widehat{\delta}=19$, X0 of the Superagui National Park and Ilha Grande National Park. Bar $=10 \mu \mathrm{m}$.
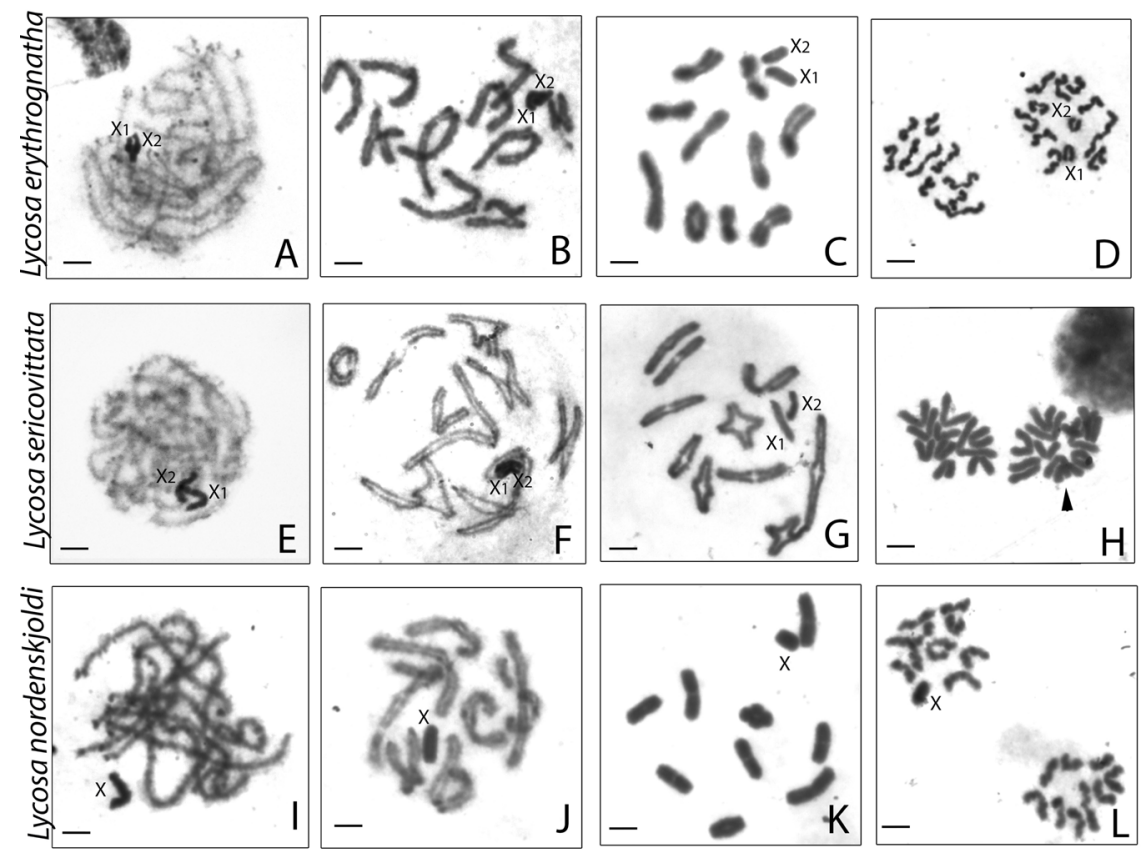

Figure 2 - Meiotic cells from Lycosa males stained with Giemsa. A-D Lycosa erythrognatha; E-H Lycosa sericovittata; I-L Lycosa gr. nordenskjoldi. Cells in pachytene $(\mathbf{A}, \mathbf{E}, \mathbf{I})$ evidence the positive heteropycnotic sex chromosomes. Diplotene cells showing sexual univalents arranged side by side $(\mathbf{B}, \mathbf{F})$ or as an isolated univalent (J); all cells showing chiasmata, mostly terminal in autosomes. Diakinesis cells confirmed the number of bivalents and sex chromosomes in each species: $(\mathbf{C})$ L. erythrognatha e (G) L. sericovittata with 10 autosomal bivalents $+\mathrm{X}_{1} \mathrm{X}_{2} 0 \mathrm{e}(\mathbf{K}) L$. gr. nordenskjoldi with 9 autosomal bivalents + X0. Metaphase II cells show joint migration of sex chromosomes $(\mathbf{D}, \mathbf{H})$ by observing cells with 12 and 10 chromosomes; and the migration of the single sex chromosome $(\mathbf{L})$ showing cells with 10 and 9 chromosomes. The arrowheads in $(\mathbf{H})$ indicate the cell with the highest chromosome number. Bar $=10 \mu \mathrm{m}$.

Metaphase II cells showed 10 and 12 chromosomes in L. erythrognatha (Figure 2D) and L. sericovittata (Figure 2H), with the sexual univalents segregation to the same pole, confirming the $\mathrm{X}_{1} \mathrm{X}_{2} 0 \mathrm{SCS}$. In $L$. gr. nordenskjoldi (Figure 2L) 10 and 9 chromosomes were detected in cells during metaphase II, thereby confirming the X0 SCS.
The C-banding applied to testicular cells of the three species (Figure 3A, B, C), showed pericentromeric heterochromatin in all chromosomes. Moreover, $L$. sericovittata also showed a chromosome pair with terminal C-bands (Figure 3B) while $L$. gr. nordenskjoldi presented some interstitial C-bands regions (Figure $3 \mathrm{C}$ ). 
The base-specific fluorochrome staining revealed interspecific differences: Lycosa erythrognatha and L. gr. nordenskjoldi (Figure 3D, F, respectively) presented $\mathrm{CMA}_{3}^{+}$ pericentromeric signals in all chromosomes, coinciding with heterochromatic regions in the former. In addition to the pericentromeric $\mathrm{CMA}_{3}^{+}$regions, $L$. sericovittata also presented GC-rich sites at terminal regions of two chromosomes (Figure $3 \mathrm{E}$ ). No DAPI ${ }^{+}$signals (AT-rich sites) were detected in the analyzed species (data not shown).

The FISH experiments revealed four 18S rDNA sites in L. erythrognatha, with interpopulation variation of $18 \mathrm{~S}$-bearing pairs. Therefore, these ribosomal cistrons were located in pairs 5 and 9 of three individuals from Mata dos Godoy State Park (PEMG) and the four specimens from the State University of Londrina (UEL) (Figure 4A), while 10 individuals from Superagui National Park (PNS) and three from Iguaçu National Park (PNI) presented positive signals in pairs 2 and 5 (Figure 4B). In L. sericovittata, FISH also identified four $18 \mathrm{~S}$ rDNA sites, at the terminal region of pairs 5 and 9 of the two individuals analyzed (Figure 4C).

In addition, inter and intrapopulational variation in the number of $18 \mathrm{~S}$ rDNA was observed in L. gr. nordenskjoldi, ranging from four, six and seven $18 \mathrm{~S}$ signals. Similarly, this species also presented variation in the pairs bearing ribosomal sites, as follows: two individuals from Ilha Grande National Park (PNIG) showed four 18S rDNA sites at terminal region of pairs 5 and 9 (Figure 5A) while two individuals from the same locality presented six sites in pairs 2,3 and 5 (Figure 5B). On the other hand, the three samples from PNS were characterized by seven $18 \mathrm{~S}$ rDNA sites at terminal region of pairs 1,5 and 8 , and on a single chromosome from pair 3 (Figure 5C).

\section{Discussion}

\section{Karyotype analysis}

The diploid numbers, presence of SCS and karyotypes composed of acrocentric chromosomes observed in $L$. erythrognatha, L. sericovittata, and L. gr. nordenskjoldi were consistent with previous reports in these species (Diaz and Saez, 1966; Chemisquy et al., 2008; Araujo et al., 2015); however, only $L$. gr. nordenskjoldi was previously analyzed in another population of the state of Paraná (Araujo et al., 2015). The occurrence of acrocentric or telocentric chromosomes is regarded as a common trait shared among species of Entelegynae (Dolejš et al., 2011; Araujo et al., 2015).

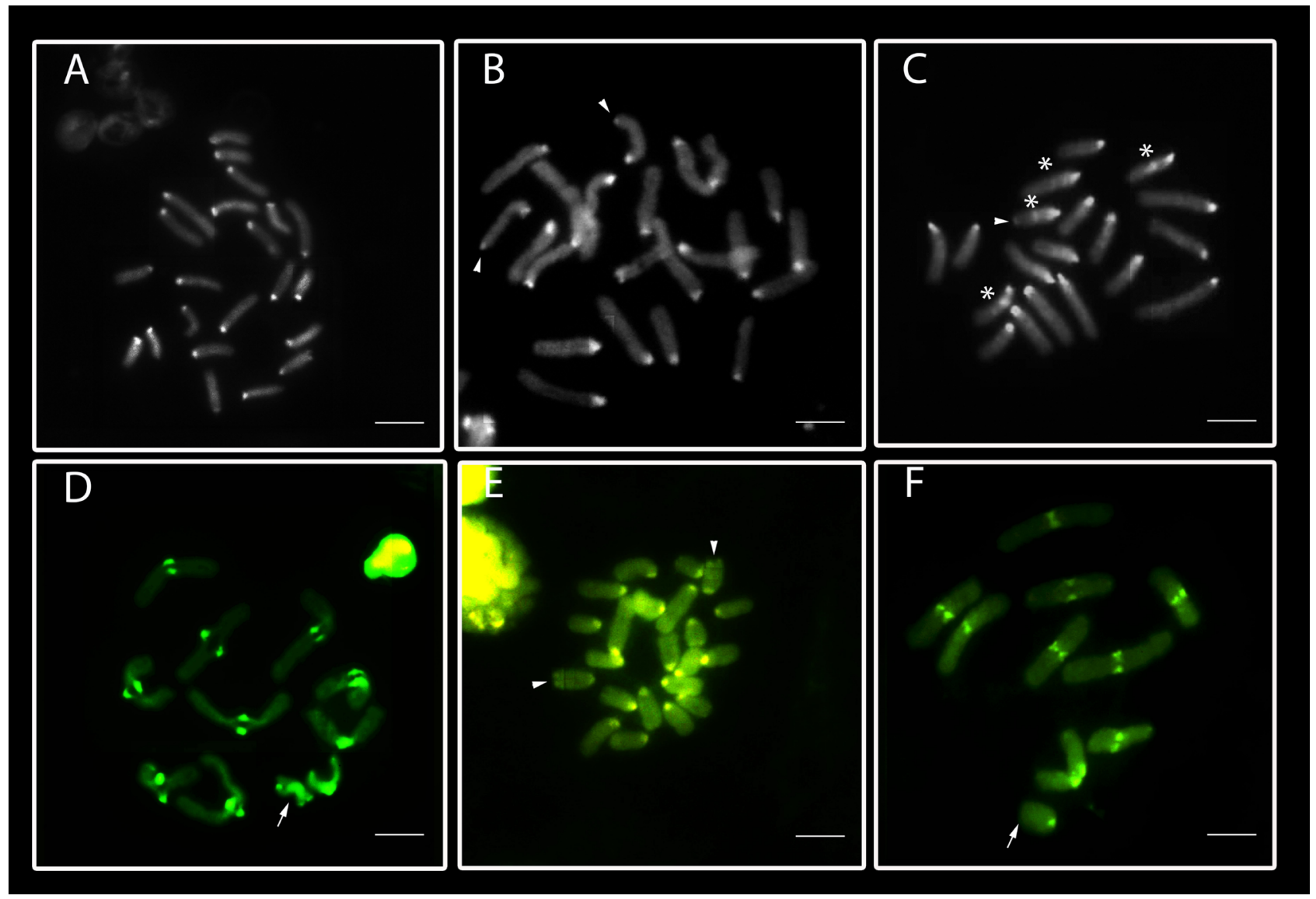

Figure 3 - Testicular cells of the three Lycosa species submitted to the $\mathrm{C}$ banding technique $(\mathbf{A}, \mathbf{B}, \mathbf{C})$ and staining with fluorochrome $\mathrm{CMA}_{3}(\mathbf{D}, \mathbf{E}$, F). The arrows indicate the sex chromosomes. In A, B, C, mitotic metaphases of $L$. erythrognatha with $2 \mathrm{n}^{\hat{\gamma}}=22, \mathrm{X}_{1} \mathrm{X}_{2} 0$ of the Mata dos Godoy State Park, State University of Londrina, Iguaçu National Park and Superagui National Park., L. sericovittata with $2 \mathrm{n} \delta=22, \mathrm{X}_{1} \mathrm{X}_{2} 0$ of the State University of Londrina, $L$. gr. nordenskjoldi with $2 \mathrm{n} \delta^{\hat{\gamma}}=19$, X0 of the Superagui National Park and Ilha Grande National Park respectively, showing pericentromeric heterochromatin on all chromosomes. In (B) some terminal heterochromatic markings (arrowheads) and in (C) interstitial heterochromatin (asterisk). In (D) diakinesis cell of L. erythrognatha with $\mathrm{CMA}_{3}^{+}$pericentromeric regions. Mitotic metaphase of $L$. sericovittata $(\mathbf{E})$ with $\mathrm{CMA}_{3}{ }^{+}$pericentromeric regions on all chromosomes: arrowheads indicate a pair of chromosomes with terminal markings. In (F) diplotene cell of $L$. gr. nordenskjoldi showing $\mathrm{CMA}_{3}^{+}$pericentromeric markings on all chromosomes. Bar $=10 \mu \mathrm{m}$. 


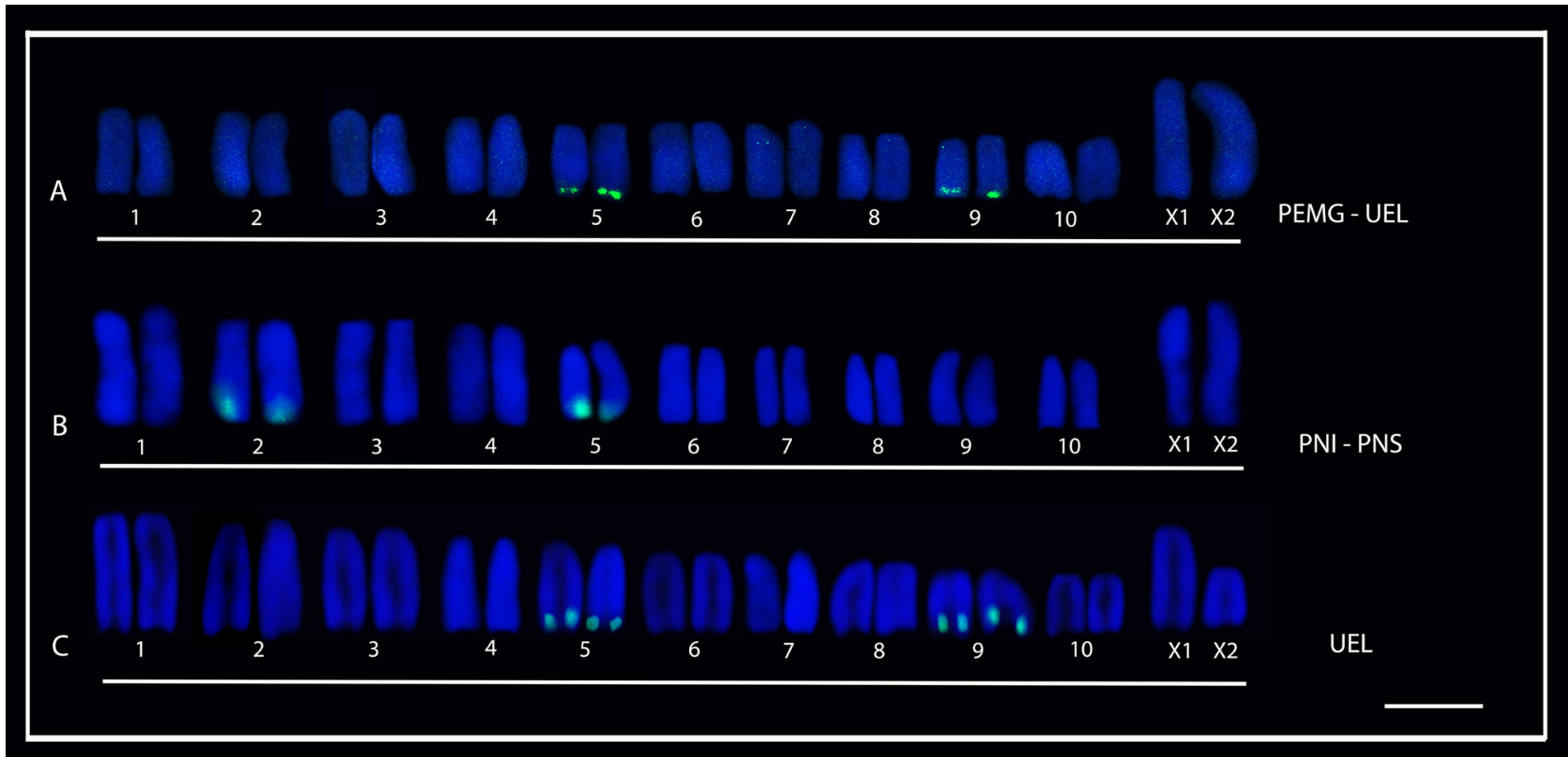

Figure 4 - Karyotypes of males of two Lycosa species submitted to fluorescent in situ hybridization (FISH) with 18S rDNA probe. In (A) and (B) $L$. erythrognatha: in (A) from Mata dos Godoy State Park (PEMG) and State University of Londrina (UEL), showing the sites of $18 \mathrm{~S}$ rDNA in pairs 5 and 9; in (B) from Iguaçu National Park (PNI) and Superagui National Park (PNS) showing ribosomal sites in pairs 2 and 5; in (C) L. sericovittata from UEL, with sites of $18 \mathrm{~S}$ rDNA in pairs 5 and 9 . Bar $=10 \mu \mathrm{m}$.

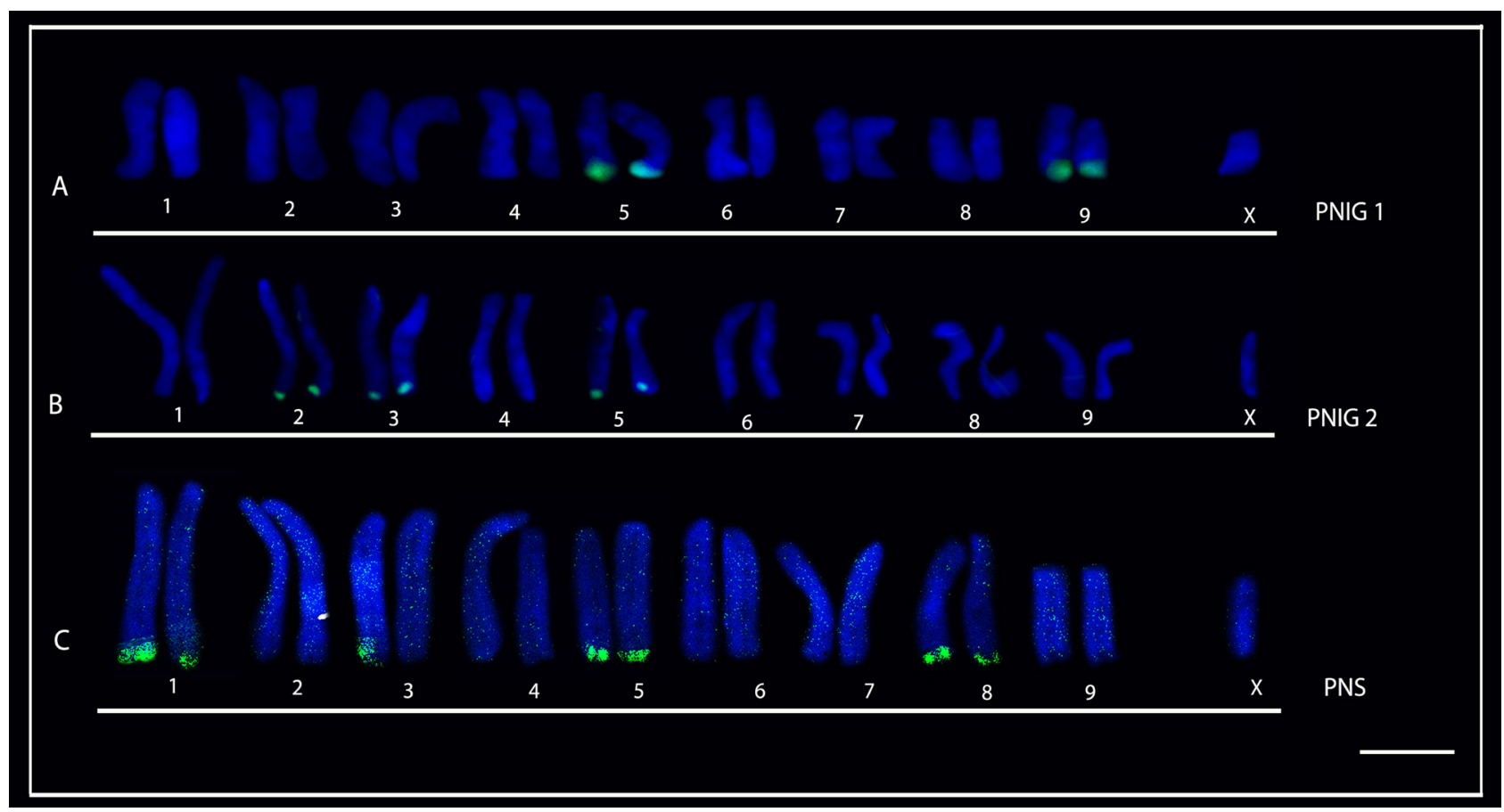

Figure 5 - Karyotypes of two populations of $L$. gr. nordenskjoldi submitted to fluorescent in situ hybridization (FISH) with 18S rDNA. (A) individual from the Ilha Grande National Park (PNIG) population with ribosomal sites in pairs 5 e 9; (B) individual from the PNIG population with ribosomal sites in pairs 2, 3 e 5; (C) Superagui National Park (PNS) population with sites of 18S rDNA in pairs 1, 3, 5 and 8; pair 3 shows marking in only one of the chromosomes. Bar $=10 \mu \mathrm{m}$.

Four congeneric species (L. chaperi Simon, 1885, L. thorelli Keyserling, 1877, L. carmichaeli Gravely, 1924 and L. pampeana Holmberg, 1876) also exhibited the pattern reported in L. erythrognatha and L. sericovittata, i.e., $2 \mathrm{n} \delta=22, \mathrm{X}_{1} \mathrm{X}_{2} 0$ (Mittal, 1966; Brum-Zorrilla and Postiglioni, 1980; Srivastava and Shukla, 1986; Chemisquy et al., 2008). On the other hand, only L. gr. nordenskjoldi and Hogna sternalis (Bertkau,
1880) presents $2 \mathrm{n} \hat{\delta}=19$, X0 (Araujo et al., 2021; present study), indicating that this is a rare diploid number within spiders of the family Lycosidae. Even though SCS $\mathrm{X}_{1} \mathrm{X}_{2} 0$ has been commonly reported in Lycosidae, being considered an ancestral condition in spiders (Araujo et al., 2016), the presence of $2 n=22$ is found in less than $20 \%$ of species in this family. Whereas most of them are characterized by $2 n=28$ 
(Araujo et al., 2021). Within the genus Lycosa genus, the available karyotypic analyzes demonstrated high frequencies of both $2 \mathrm{n}$ values, followed by a less frequent occurrence of diploid numbers, ranging from 18 to 27 chromosomes (Araujo et al., 2021).

It should be pointed out that species of Lycosa show considerable levels of chromosomal variation in spite of the low number of species analyzed so far. This feature and the fact that this genus is recognized as a polyphyletic group composed of many species, jeopardizes reliable estimates about the ancestral diploid number in Lycosa and their karyoevolutionary relationships.

\section{Patterns of heterochromatin distribution}

The three species analyzed shared the common pattern of heterochromatin distribution described by Chemisquy et al. (2008), including C-bands and GC-rich segments at pericentromeric regions. However, variations were found in these species, such as the presence of GC-rich terminal sites in a specimen of $L$. sericovittata. Moreover, $L$. gr. nordenskjoldi was characterized by heterogeneity of heterochromatin distribution due to the occurrence of pericentromeric, interstitial and terminal C-bands while GC-rich sequences were restricted to the pericentromeric region. Therefore, two additional patterns of C-banding were identified in this study: (1) the presence of terminal GC-rich heterochromatin segments; and (2) interstitial heterochromatin with no signs of GC or AT richness ( $\left.\mathrm{CMA}_{3}{ }^{-} / \mathrm{DAPI}^{-}\right)$.

The distribution of heterochromatic blocks at pericentromeric regions, had been considered as distinctive feature within Lycosidae, as supported by the data reported by Chemisquy et al. (2008) and the present results. Nevertheless, our data demonstrated novel patterns of heterochromatin distribution in this group of spiders in which $L$. gr. nordenskjoldi stands out by the high dispersal of heterochromatin segments. A comparative analysis between these results and the putative ancestor pattern of heterochromatin distribution in Lycosa suggests that paracentric inversions or dispersal of repetitive sequences could be related to the C-banding pattern described in L. gr. nordenskjoldi.

The variability in the data obtained by C-banding and fluorochrome staining, particularly in Lycosa gr. nordenskjoldi, in addition to the diploid number, confirms that traditional chromosomal markers allow differentiating congeneric species, at least in comparison with data described in literature so far.

\section{Interpopulation chromosomal variability of 185 rDNA sites}

Despite the presence of two 18S rDNA-bearing pairs in L. erythrognatha, this species showed interpopulation variation in the position of these sites in different chromosomes in the karyotypes. The Superagui National Park (PNS), located on the northern coast of the state of Paraná, is a region of islands and mangroves with a more tropical climate, similar to that of the Iguaçu National Park (PNI) in the western boundary of Paraná, which includes one of the largest conserved areas of Atlantic Forest in Brazil. The populations of L. erythrognatha from both regions (PNS and PNI) exhibited a different karyotypic pattern in relation to those from the northern region (PEMG and UEL), a region of dry climate and characterized by semideciduous seasonal forest vegetation. In spite of the geographic distance between these locations (PNS and PNI), which is about 560 $\mathrm{km}$, we infer that adaptive processes in these populations should be comparable to each other because they share similar habitats. Analogously, the environmental differences among the four populations should impose differential selective pressure, thereby determining distinct evolutionary pathways.

This interpopulation variation in $18 \mathrm{~S}$ rDNA-bearing pairs may be related to gene dispersal via transpositions or translocations, as suggested by Cabral de Melo et al. (2011) in a study with beetles (Scarabaeinae). These authors point out that in the absence of significant karyotypic changes (e.g., increase or decrease in diploid numbers), the ribosomal sites can disperse and vary as a result of successive amplification processes of these cistrons, particularly when located at distal portion of chromosomes inasmuch as these regions are considered highly dynamic, thus favoring the dispersal of rDNA copies throughout the genome.

The distribution of ribosomal sites in L. gr. nordenskjold $i$ showed both inter and intrapopulation variation. The variability between the two populations (PNS and PNIG) of this species also can be related to their habitat. Despite being similar to each other, the evolutionary pressure can act in different ways on populations from distinct species, eventually resulting in independent accumulation of chromosomal rearrangements in locally adapted individuals, as previously reported in Wadicosa fidelis (Forman et al., 2013) and in harvestmen species (Opiliones, Phalangiidae) (Št'áhlavský et al., 2018).

On the other hand, the presence of $18 \mathrm{~S}$ rDNA sites in pairs 5 and 9 was shared by the three species, with pair 5 observed in all populations, despite the variability in location and number of ribosomal cistrons. Apparently, this would be a conserved trait in these species what remains to be confirmed by further studies, since this is the first report based on FISH experiments in Lycosa.

\section{Chromosomal diversification within Lycosinae}

Recent phylogenetic inferences (Piacentini and Ramiréz, 2019), revealed that most species of Lycosidae from south America represent undescribed genera, what should explain the karyotypic diversity observed in literature and in the present work. Furthermore, the South American species usually present lower diploid numbers than Eurasian representatives (Araujo et al., 2021).

In addition, the phylogenetic reconstruction presented by Piacentini and Ramiréz (2019), Lycosinae encompasses species from North and South American, as well as the genus Hogna and Eurasian species of Lycosa. The latter, along with the outgroup Pardosinae, has a predominance of species with $2 \mathrm{n}=28, \mathrm{X}_{1} \mathrm{X}_{2} 0$ (Araujo et al., 2021), which can be suggested as the ancestral diploid number of the Lycosinae subfamily.

Only six out of the total of cytogenetically analyzed species in Lycosinae (Araujo et al., 2021) are characterized by changes in the diploid number involving sex chromosomes, as follows: Hogna sternalis (Bertkau, 1880) - 2n $\hat{\bigcirc}=19$, X0; Lycosa barnesi Gravely, 1924-2n $\hat{0}=27, \mathrm{X} 0$ (Eurasian region); L. gr. nordenskjoldi Tullgren, 1905-2n ${ }^{\lambda}=19$, X0; Lycosa sp. - 2n $\hat{\sigma}=21, \mathrm{X}_{1} \mathrm{X}_{2} \mathrm{Y}$; Lycosa (thorelli group) $-2 \mathrm{n} \hat{\sigma}=23$, $\mathrm{X}_{1} \mathrm{X}_{2} \mathrm{X}_{3} 0$; and Schizocosa (malitiosa group) - $2 \mathrm{n} \hat{\varnothing}=23, \mathrm{X} 0$. 
Analyzing the data presented in Araujo et al. (2021), these unusual diploid numbers were determined by alterations in the SCS, related to increases or decreases in the number of chromosomes with the consequent evolution of new SCS. As mentioned earlier, $\mathrm{X}_{1} \mathrm{X}_{2} 0 \mathrm{SCS}$ is regarded as an ancestral condition for several groups of spiders, including Lycosoidea (Dolejš et al., 2011; Araujo et al., 2015). Thus, other SCS systems should be considered as derived features. Some studies, including those by Král et al. (2006) and Araujo et al. $(2012,2014)$, have previously demonstrated that $\mathrm{X}_{1} \mathrm{X}_{2} \mathrm{X}_{3} 0$ and $X_{1} X_{2} 0$ SCS coexist within a single genus or, even, in the same species (Araujo et al., 2014; Rincão et al., 2020).

The origin of the above mentioned SCSs in Entelegynae was hypothesized by several authors as follows: 1) by fusions or fissions in the sex chromosomes during the conversion of $\mathrm{X}_{1} \mathrm{X}_{2} 0$ to $\mathrm{X}_{1} \mathrm{X}_{2} \mathrm{X}_{3} 0$ system and vice versa, and during the conversion of $X_{1} X_{2} 0$ to a single $X 0$ system (Pätau, 1948; Postiglioni and Brum-Zorrilla, 1981; Parida and Sharma, 1986); 2) by the formation of a supernumerary element during the conversion of $\mathrm{X}_{1} \mathrm{X}_{2} 0$ to $\mathrm{X}_{1} \mathrm{X}_{2} \mathrm{X}_{3} 0$ system (BoleGowda, 1952); and 3) by fusions between sex and autosomal chromosomes, especially during the conversion of $\mathrm{X}_{1} \mathrm{X}_{2} 0$ to $\mathrm{X}_{1} \mathrm{X}_{2} \mathrm{Y}$ system (Král et al., 2006). Despite this great variability in SCS, Entelegynae spiders share two notable characteristics, which are the predominance of acrocentric chromosomes and the occurrence of $\mathrm{X}_{1} \mathrm{X}_{2} 0 \mathrm{SCS}$ (Král et al., 2006; Araujo et al., 2014), which is observed in Lycosinae.

One of the most cited chromosomal rearrangements is the fusion between autosomes and sex chromosomes, as proposed by Hackman (1948), resulting in metacentric elements, usually followed by pericentric inversions or partial deletion (Datta and Chatterjee, 1989, 1992). Another event often hypothesized within this context would be the in tandem fusion, resulting in the origin of acrocentric chromosomes (Pekár and Král, 2001). When changes in diploid number take place without modifications in the $\mathrm{X}_{1} \mathrm{X}_{2} 0 \mathrm{SCS}$, rearrangements such as single translocation or in tandem fusion among autosomal chromosomes are inferred, thus maintaining the acrocentric/ telocentric chromosomal set. Such event might have caused the differentiation of karyotypes with $2 \mathrm{n} \hat{\jmath}=26,24,22$ and 18 . These diploid numbers are reported, for example, in Gladicosa pulchra (Keyserling, 1877); Lycosa madani Pocock, 1901; Schizocosa malitiosa (Tullgren, 1905); and Lycosa tarantula (Linnaeus, 1758), respectively.

On the other hand, when changes in both diploid numbers and SCS occur, the even diploid number is modified into an odd chromosome number. In this case, an $\mathrm{X}_{1} \mathrm{X}_{2} 0 \mathrm{SCS}$ originates the novel and less frequent systems: $\mathrm{X} 0, \mathrm{X}_{1} \mathrm{X}_{2} \mathrm{X}_{3} 0$ and $\mathrm{X}_{1} \mathrm{X}_{2} \mathrm{Y}$, present in some species of Lycosa (South America) associated with distinctive morphology of sex chromosomes. Accordingly, the $\mathrm{X}_{1} \mathrm{X}_{2} \mathrm{X}_{3} 0$ system could have arisen from the insertion of a supernumerary chromosome in the former $X_{1} X_{2} 0$ SCS (Bole-Gowda, 1952) or from chromosomal nondisjunction (Postiglioni and Brum-Zorrilla, 1981; Datta and Chatterjee, 1988). Additionally, the $\mathrm{X}_{1} \mathrm{X}_{2} \mathrm{Y}$ SCS could emerge after a translocation between sex and autosomal chromosomes (Silva et al., 2002; Rowell, 2004; Král et al., 2006, 2007).

Therefore, the presence of lower diploid numbers and unusual SCS is likely to derive from karyotypes with similar
$2 \mathrm{n}$ values instead of a series of fusions in former karyotypes with $2 \mathrm{n} \hat{\sigma}=28$. For example, the occurrence of $2 \mathrm{n} \hat{\sigma}=23$, $\mathrm{X}_{1} \mathrm{X}_{2} \mathrm{X}_{3} 0$ should rather evolve from $2 \mathrm{n} \delta^{\Uparrow}=22, \mathrm{X}_{1} \mathrm{X}_{2} 0$ by the formation of a supernumerary element than through multiple fusion/fission events.

Otherwise, the karyotypes with $2 \mathrm{n} \sigma^{\hat{N}}=27, \mathrm{X0} ; 2 \mathrm{n}{ }^{\hat{0}}=23$, $\mathrm{X} 0$; and $2 \mathrm{n} \hat{\sigma}=19, \mathrm{X} 0$ would have emerged through fusions between sex chromosomes, followed by a putative pericentric inversion. These derived SCSs are present in many other spider families along with other systems, but they have been rarely reported (Král et al., 2006; Araujo et al., 2012, 2014).

In conclusion, this study demonstrated a wide variation in chromosomal features among and within the three species of Lycosa, as evidenced by the differences in both number and location of $18 \mathrm{~S}$ rDNA sites and heterochromatic blocks, especially in the species complex Lycosa gr. nordenskjoldi. The data also showed that genomes have undergone chromosomal breaks and translocation/chromosome fusions, which account for the differentiation of diploid numbers and sex chromosomes system in species of Lycosinae.

\section{Acknowledgements}

This research was supported by a grant from Coordenação de Aperfeiçoamento de Pessoal de Nível Superior - Brazil (CAPES) - Finance code 001, Fundação Araucária (agreement 001/2017), Fundação Grupo Boticário (agreement 013/2018), and by the CNPq (303028/2014-9 to ADB and 169739/2018-0 to AFC). The authors thank Robson Rockembacher (UEL) for their assistance with sample collection; the Instituto Chico Mendes de Conservação da Biodiversidade (ICMBio) and Instituto Ambiental do Paraná (IAP) for the assistance in the Conservation Units sampled.

\section{Conflict of Interest}

The authors have no conflicts of interest to declare

\section{Author Contributions}

ALD, AFC and MPR conceived and designed the study, MPR collected the samples, ADB curatorial data; AFC performed the cytogenetic analysis, FCD and MPR assistance in methodology; AFC wrote the manuscript and designed the figures. All authors read and approved the final version.

\section{References}

Araujo D, Rheims CA, Brescovit A and Cella DM (2008) Extreme degree of chromosome number variability in species of the spider genus Scytodes (Araneae, Haplogynae, Scytodidae). J Zool Syst Evol Res 46:89-95.

Araujo D, Schneider MC, Paula-Neto E and Cella DM (2012) Sex chromosomes and meiosis in spiders: A review. In: Swan A (eds) Meiosis-molecular mechanisms and cytogenetic diversity. InTech Open, Rijeka, pp 87-108.

Araujo D, Oliveira EG, Giroti AM, Mattos VF, Paula-Neto E, Brescovit AD, Schneider MC and Cella DM (2014) Comparative cytogenetics of seven Ctenidae species (Araneae). Zool Sci $31: 83-88$

Araujo D, Oliveira EG, Giroti AM, Mattos VF, Paula-Neto E, Brescovit AD, Schneider MC and Cella DM (2015) Chromosome evolution in lycosoid spiders (Araneomorphae): A scenario based on analysis of seven species of the families Lycosidae, Senoculidae and Trechaleidae. J Arachnol 43:174-181. 
Araujo D, Sanches MB, Da Silva J, Lima GS, Nascimento EVJ, Giroti AM, Brescovit AD, Cella DM and Schneider MC (2016) Chromosomal analyses of Salticinae and Lyssomaninae reveal a broad occurrence of the $2 \mathrm{n} \hat{\gamma}=28, \mathrm{X} 1 \mathrm{X} 20$ karyotype within Salticidae. J Arachnol 44:148-152.

Bole-Gowda BN (1952) Studies on the chromosomes and the sexdetermining mechanism in four hunting spiders (Sparassidae). Proc Zool Soc 5:51-70.

Brum-Zorrilla N and Cazenave AM (1974) Heterochromatin localization in the chromosomes of Lycosa malitiosa (Arachnida). Experientia 30:94-95.

Brum-Zorrilla N and Postiglioni A (1980) Karyological studies on Uruguayan spiders I. Banding pattern in chromosomes of Lycosa species (Araneae-Lycosidae). Genetica 54:149-153.

Cabral-de-Mello DC, Oliveira SG, de Moura RC and Martins C (2011) Chromosomal organization of the 18S and 5S rRNAs and histone $\mathrm{H} 3$ genes in Scarabaeinae coleopterans: Insights into the evolutionary dynamics of multigene families and heterochromatin. BMC Genet 12:88.

Chemisquy MA, Gil SGR, Scioscia CL and Mola LM (2008) Cytogenetic studies of three Lycosidae species from Argentina (Arachnida, Araneae). Genet Mol Biol 31:857-867.

Datta SN and Chatterjee K (1988) Chromosomes and sex determination in 13 araneid spiders of North-Eastern India. Genetica 76:91-99.

Datta SN and Chatterjee K (1989) Study of meiotic chromosomes of four hunting spiders of Northeastern India. Perspect Cytol Genet 6:414-424.

Datta SN and Chatterjee K (1992) Chromosomes and sex determination in three species of spinner spiders from Northeastern India. Cell Chromosome Res 15:64-69.

Diaz MO and Saez FA (1966) Karyotypes of South American Araneida. Mem Inst Butantan Simp Int 33:153-154.

Dolejš P, Kořínkova T, Musilová J, Opatová V, Kubcová L, Buchar J and Král J (2011) Karyotypes of central European spiders of the genera Arctosa, Tricca and Xerolycosa (Araneae:Lycosidae). Eur J Entomol 108:1-16.

Forman M, Nguyen P, Hula V and Král J (2013) Sex chromosome pairing and extensive NOR polymorphism in Wadicosa fidelis (Araneae: Lycosidae). Cytogenet Genome Res 141:43-49.

Hackman W (1948) Chromosomenstudien an Araneen mit besonderer Berücksichtigung der Geschlechtschromosomen. Entomol Fenn 54:1-101.

Král J (2007) Evolution of multiple sex chromosomes in the spider genus Malthonica (Araneae: Agel- enidae) indicates unique structure of the spider sex chromosome systems. Chromosome Res 15:863-879.

Král J, Musilová, J, Št'áhlavský F, Řezáč M, Akan Z, Edwards RL, Coyle FA and Almerje CR (2006) Evolution of the karyotype and sex chromosome systems in basal clades of araneomorph spiders (Araneae: Araneomorphae). Chromosome Res 14:859-880.

Levan A, Fredga K and Sandberg AA (1964) Nomenclature for centromeric position on chromosomes. Hereditas 52:201-220.

Lui RL, Blanco DR, Moreira-Filho O and Margarido VP (2012) Propidium iodide for making heterochromatin more evident in the C-banding technique. Biotech Histochem 87:433-438.

Mittal OP (1966) Karyological studies on the Indian spiders I. A comparative study of the chromosomes and sex-determining mechanism in the family Lycosidae. Caryologia 19:385-394.

Navia JFF, Vizzareta RO and Yunque EL (2006) Observaciones cromossómicas en la araña Lycosa sp. (Arachnida). El Antoniano 111:91-92.

Parida BB and Sharma NN (1986) Karyotype and spermatogenesis in an Indian hunting spider, Sparassus sp. (Sparassidae: Arachnida) with multiple sex chromosomes. Chromosome Inf Serv 40: 28-30.

Pätau K (1948) X-segregation and heterochromasy in the spider Aranea reaumuri. Heredity (Edinb) 2:77-100.
Pekár S and Král J (2001) A comparative study of the biology and karyotypes of two central European Zoodariid spiders (Araneae, Zodariidae). J Arachnol 29:345-353.

Piacentini LN and Ramírez MJ (2019) Hunting the wolf: A molecular phylogeny of the wolf spiders (Araneae, Lycosidae). Mol Phylogenet Evol 136:227-240.

Postiglioni A and Brum-Zorrilla N (1981) Karyological studies on Uruguayan spiders II. Sex chromosomes in spiders of the genus Lycosa (Araneae-Lycosidae). Genetica 56:47-53.

Rincão MP, Chavari JL, Brescovit AD and Dias AL (2017) Cytogenetic analysis of five Ctenidae species (Araneae): Detection of heterochromatin and 18S rDNA sites. Comp Cytogenet 11:627-639.

Rincão MP, Brescovit AD and Dias AL (2020) Insights on repetitive DNA behavior in two species of Ctenus Walckenaer, 1805 and Guasuctenus Polotow and Brescovit, 2019 (Araneae, Ctenidae): Evolutionary profile of $\mathrm{H} 3$ histone, $18 \mathrm{~S}$ rRNA genes and heterochromatin distribution. PLoS One 15:e231324.

Rowell DM (2004) Fixed fusion heterozigosity in Delena cancerides Walck. (Araneae: Sparassidae): An alternative to speciation by monobrachial fusion. Genetica 80:139-157.

Schneider CA, Rasband WS and Eliceiri KW (2012) NIH Image to ImageJ: 25 years of image analysis. Nat Methods 9:671-675.

Schwarzacher T and Heslop-Harrison JS (2000) Pratical in situ hybridization. BIOS Scientific Publishers Ltda, Oxford, 216 p.

Schweizer D (1980) Simultaneous fluorescent staining of R bands and specific heterochromatic regions (DA/DAPI bands) in human chromosomes. Cytogenet Cell Genet 27:190-193.

Silva RW, Klisiowicz DR, Cella DM, Mangili OC and Sbalqueiro IJ (2002) Differential distribution of constitutive heterochromatin in two species of brown spider: Loxosceles intermedia and L. laeta (Araneae, Sicariidae), from the metropolitan region of Curitiba, PR (Brazil). Acta Biol Paranaense 31:123-136.

Srivastava MDL and Shukla S (1986) Chromosome number and sex-determining mechanism in forty-seven species of Indian spiders. Chromosome Inf Serv 41:23-26.

Št’áhlavský F, Opatova V, Just P, Lotz LN and Haddad CR (2018) Molecular technique reveals high variability of $18 \mathrm{~S}$ rDNA distribution in harvestmen (Opiliones, Phalangiidae) from South Africa. Comp Cytogenet 12:41-59.

Sumner AT (1972) A simple technique for demonstrating centromeric heterochromatin. Exp Cell Res 75:304-306.

Wheeler WC, Coddington JA, Crowley LM, Dimitrov D, Goloboff PA, Griswold CE, Hormiga G, Prendini L, Ramírez MJ, Sierwald P et al. (2017) The spider tree of life: Phylogeny of Araneae based on target-gene analyses from an extensive taxon sampling. Cladistics 33:574-616.

Wise D (1983) An electron microscope study of the karyotypes of two wolf spiders. Can J Genet Cytol 25:161-168.

\section{Internet Resources}

Araujo D, Schneider MC, Paula-Neto E and Cella DM(2021) The spider cytogenetic database, http://www.arthropodacytogenetics.bio. br/spiderdatabase/ (accessed 15 April 2021).

Sakamoto Y and Zacaro AA (2009) LEVAN, an Image J plugin for morphological cytogenetic analysis of mitotic and meiotic chromosomes. Initial version, https://imagej.nih.gov/ij/plugins/ levan/levan.html (accessed 16 September 2019).

World Spider Catalog (2021) World Spider Catalog. Version 19.5. Natural History Museum Bern, http://wsc.nmbe.ch (accessed 12 April 2021).

Associate Editor: Maria José de Jesus Silva

License information: This is an open-access article distributed under the terms of the Creative Commons Attribution License (type CC-BY), which permits unrestricted use, distribution and reproduction in any medium, provided the original article is properly cited. 